\title{
Is the Quality of Governance a Good Pointer to the General Economic Health of the Country?
}

\author{
P. Madumi
}

\author{
Stellenbosch University, South Africa
}

\begin{abstract}
Good governance is believed to be instrumental in facilitating an environment for sustainable economic growth, especially for developing countries. It is no surprise that there is a growing public interest in the interplay of political and economic systems in South Africa. The chief concern is that the country is plagued by a couple of economic challenges such as sluggish gross domestic product (GDP) growth, poverty, lack of service delivery, poor financial management, weak business confidence, massive unemployment, and corruption are threats to the economic growth. It is generally believed that good governance would minimize persistent ills of the economy and ultimately pave the way for restoring economic growth. But is the quality governance the principal stimulus of a country's economic growth? This is the chief questions which this article will attempt to answer. Based on the good governance and neoclassical growth theory, and good governance theory, this article seeks to analyse and evaluates the impact of the quality of governance on the growth of the economy in South Africa.
\end{abstract}

Keywords: Corruption, Economic growth, good governance, neoclassical and poor governance.

\section{INTRODUCTION}

Recently, South Africa has struggled to grow the economy above $2 \%$ of the GDP growth rate. The International Monetary Fund (IMF) projects that the country's GDP growth rate will decline from $1.4 \%$ to $1.2 \%$ in 2019 . Ordinarily, for the government to address the chronic problems of poverty, inequality, and high unemployment, which are agonizing the society, South Africa's economy should at least grow at rate above $3 \%$ percent of the GDP. Broadly speaking, economic growth is a splendid tool with which the government can utilize to combat most of the socio-economic problems. For example, when the economy grows businesses in the country boom, allowing firms to hire more workers and increasing their income. Thus, basically reducing unemployment, inequality, and poverty. This is not by all means or any rate to suggest that economic growth is the panacea to all these socioeconomic problems. Nevertheless, it is obvious that when the economy fails to grow these economic challenges tend to maintain or augment their aggression against society. For that reason, the government shall make every effort to foster economic growth. Now, the pertinent question is, why is South Africa as one of the biggest economies in Africa failing to grow the economy at least above $2 \%$ growth rate? Moreover, this raises the question of the driving forces that determine growth.

It would be extremely naïve to ignore the significance of the quality of the governance when

*Address correspondence to this author at the Stellenbosch University, South Africa; Tel: 022702 3126; Fax: 022702 3060;

E-mail: p.madumi@ma2.sun.ac.za answering the aforementioned question because there is no doubt that the government plays a crucial role in facilitating the economic growth of the country. In short, governance is a center of economic growth and without it, there may be no economic growth. Generally, one of the government roles is to create policies which seek to manipulate the national budget in response to economic conditions, and these policies can either engineer economic growth or destroy the economy. Certainly, most of the people in South Africa are living in conditions of poverty, inequality, unemployment, corruption, abuse of the law, and public service failure amongst others (World Bank, 2019).

Understandably, the debate about economic growth and governance has become the concern of all South African from all walks of life. Ideally, the majority of the people perceive good governance as a universal remedy for all economic and political problems that are confronting the country today. Without a doubt, good governance is a good idea, but is it the major determinant of economic growth? Or is it overstated? This article employs good governance and neoclassical growth theory in an attempt to analyse and evaluate whether the quality of governance is or not the principal stimulus of a country's economic growth. It starts with a theoretical context of good governance and its role in the economy, and the neoclassical growth perspectives on growth. The second part of this article reviews good governance in South Africa and the last section summarizes the conclusions and recommendations.

\section{THEORETICAL CONTEXT}

This article utilizes good governance and neoclassical growth theory as a theoretical framework 
and a method of analysis to examine how to study the impacts of the Quality of Governance on the growth of the economy in South Africa.

\subsection{Definitions of Governance and Good Governance}

Francis Fukuyama (2013) defines governance as a government's ability to make and enforce rules, and to deliver services, regardless of whether that government is democratic or not. Moreover, Fukuyama equates governance with government effectiveness. There are various definitions of good governance. For instance, Schneider (1999) defines good governance as the exercise of control to manage a country's affair. According to Johnston (2004), good governance is competent management of a country's resources and affairs in a manner that is open, transparent, accountable, equitable and responsive to people's needs. On the other hand, the United Nations Development Programme (UNDP) defines good governance as striving for rule of law, transparency, effectiveness/efficiency, accountability, and strategic vision in the exercise economic, and administrative (UNDP, 2002).

While Kaufmann, Kraay, and Mastruzzi (2010: 3) describe as "the exercise of authority through formal and informal traditions and institutions for the common good, thus encompassing: (i) the process of the selection, monitoring and replacement of governments; ii) the power of the government to effectively establish and perform sound policies; and (iii) the respect of citizens and the state for the institutions that govern economic and social interactions among them". True, from this perspective, it is hard to ignore the significant role which a government could play in the process of fostering the economy. Moreover, in the event there is good governance in the economy, the general assumption is that there will be a sustainable economic expansion. Considering that there is an abundance of good governance definitions, this article adopts the above Kaufmann et al. (2010) description as an operational definition of this article.

Kaufmann, Kraay, and Mastruzzi (2005) have developed a good governance index and a framework that the World Bank has also adopted. This index has following six main pillars: (i) accountability and responsibility of governance - assessment of political and human rights; (ii) political stability and lack of violence - assessment of violent and terroristic acts; (iii) governance efficiency - the quality of public services; (iv) legal framework - assessment of politics, which stumble the free market; (v) law enforcement implementation of contracts, court verdicts, etc. (vi) corruption control - abuse of office for personal profits. Of course, this is a well-formed a list of characteristics of how government should carry out its mandate with success, and these are positive qualities that any government which is serious with good governance should assess itself based on them. Because good governance promotes efficient utilization of resources and ultimately it will promote the growth of the economy. However, an area of concern is that there is no clear or concrete evidence that supports the relationship between good governance and economic growth except perceptions. Even econometric approaches cannot conclusively show that good governance is a requirement for economic growth. Notwithstanding, that the World Bank (2017: 66) suggests that researchers such as Klapper and Love (2004), and Claessens (2006) provide evidence that achieving sound corporate governance promotes economic growth and development.

\subsection{Governance and Economic Growth}

Governance widely considered to be the most important catalyst of economic growth and most scholars and policy analysts concur that there is a link between the two. Scholars such as (Kaufmann et al. 2000; Knack 2003), suggest that this consensus is no surprise because good governance is a pre-requisite to sustained increases in living standards. On the other hand, poor governance gives ground for corruption that will distort the economy in one way or the other. Of course, the leadership that is in ignorance of or perpetuating corruption tend to undermine the public's trust in its government. It also threatens market integrity, distorts competition, and endangers economic development (Kaufmann et al. 2000).

Importantly, the governance approach encompasses wide range components on how to govern a country, these including economic policies, and regulatory framework. Acemoglu et al. (2005) affirm that government has the potential to affect economic growth via many various channels because it is the main determinant of the economic environment and an institution that have a significant impact on the decision-making process of key economic actors. Thus, it has the ability to affect investments in both physical and human capital and technology. Arguably, these production factors are major drivers of economic growth. Similarly, Mankiw (1992: 88) dealt with the link 
between governance and economic growth through the human capital (measured by life expectancy and secondary schooling). Mankiw further asserts that life expectancy is an indicator of the health of the labour force and its use is to predict the maximum capacity of adult agents to exercise their skills. Along the same line, Morlino (2004) argues that developing countries that well governed tend to provide basic service to its citizens in general. On the contrary, Mauro (1995: 683) claims that bribery can hurt economic growth and that education in developing countries is the most affected field.

The importance of good governance is also experienced through a government's ability to offer its citizen property rights. The link between property rights and economic growth is inextricable. Accordingly, a well-functioning government should empower its people with property rights in order to ensure that resolving the competition problem over economic resources occurs in harmony. Hypothetically, without property rights, most people will be unwilling to invest in an economy because there will be no guarantee ownership. In other words, property rights increase economic efficiency and lead to economic growth because intuitively, people love incentives and enjoy possession. Scholars such as Alchian and Demsetz (1972), and Coase (1974) draws a conclusion that property rights reduce conflicts and facilitate cooperation between agents. In addition, Clague (1997) endorses the need property rights more especially when the resources are scarce, for instance, as a result of population growth, there are resource constraints. Arguing in the similar veins, Mijiyawa (2013) suggests that if the country wants to grow its economy the property rights institutions really matter.

Of all the truisms about the correlation between good governance and economics, it is worth to mention that there are some critics of this approach. Although some advocates of neo-institutional economics, such as Douglass North (1990) and Mancur Olson (1996) concur that there is a positive relationship between the quality of institutions and governance structures and economic growth. North (1990:20) cautions us against too much optimism about institutions and against teleological arguments about economic progress by arguing that institutions are not neutral actors: "Institutions are not necessarily or even usually created to be socially efficient; rather they, or at least the formal rules, are created to serve the interests of those with the bargaining power to create new rules". Kurtz and Shrank (2007) highlight this correlation can be only theoretical and there is not enough evidence to support it. They claim that the relationship between economic growth and good governance can be obvious only in developed countries or in a very long period of time. Similarly, Rothstein (2011) reveals that it is not clear that a well-governed state is one that has ruthlessly efficient concentration camp guards as opposed to bribable ones.

To sum, it is noteworthy to acknowledge that inasmuch as poor governance can negatively impact economic growth, poor economic growth can affect the quality of governance. Ironically, scholars, policymaker and ordinary people often give much attention to the negative impacts that poor governance has on the economy. Certainly, Poor economic growth tends to raise the cost of running the government, and this might exacerbate socio-economic challenges that a country has. Thus, cost of governance makes it difficult for governments to implement their intended development plans.

\subsection{Neoclassical Theory Perspectives on Growth}

The perspective of the neoclassical theory is centralized on the organization and allocation of scarce resources. It asserts that the growth rate depends on saving, population growth and technical change, and both taken as determined exogenously outside the model. The assumption is that higher propensity to save leads to a higher level of output per capita and state growth rate. On the other hand, it argues that faster population growth reduces per capita output and consumption (Solow, 1956: 90). This theory also argues that technological change has a major influence on the economy. In other words, without technological advances, otherwise, the economy will remain stuck. It seems logical because our personal life is highly dependent on new technological development. Moreover, Technology has advanced in years and it has changed our lives in one way or another. For instance, technology has changed the way we communicate, travel, does business and so forth. Prominent scholars such as (Ramsey, 1928; Cass, 1965; Koopmans, 1965) predict that in the long run, population growth and technology will exogenously determine growth.

The source of the neoclassical theory of growth can be traced to the Solow-Swan model (Solow, 1956; Swan, 1956). These authors argue that saving has a positive force on the rate of economic growth. Solow (1956) postulates that economic growth results from 
capital accumulation through household savings. He further argues that such accumulation continues until the stage of unconditional convergence as diminishing marginal returns to capital set in. James Meade concurs that income saved affects the stock of capital, but not the rate of capital accumulation, thus in a state of steady economic growth (Meade, 1962, viii). In a nutshell, these scholars regard capital accumulation as the source of increasing returns.

The aforementioned models were followed later by "learning by doing" or "learning by using" as an engine of growth. Put simply, this model looks at investment in education as a source of economic growth. Noteworthy to mention is that this model was firstly articulated by Adam Smith. Smith (1776) submits that the technological improvement in the form of "learning by doing" or "learning by using" with economies of scale through to the concept of division of labour in the process of the wealth of nations. Furthermore, studies such as (Stiglitz 1987; Romer 1986, Lucas 1988), argue that the growing gap between the more and less developed countries continues to expand because of their learning-by-doing difference. It makes sense because the premise is that "learning-by-doing" increases the stock of knowledge and human capital, and other factors such as yield quality of labour. For instance, Kaldor (1956) posits that per capita income was indeed an increasing function of per capita investment. Meaning that learning was regarded as a function of the rate of increase in investment. In the same manner, Arrow (1962) argues that new machines are improved and more productivity will result as the function of the cumulative which will also increase investment for the industry because new knowledge should be discovered as the result of the investment. Arguably, these scholars have made a huge contribution to our understanding of the factors that determine the rate of economic growth for different countries.

In summation, first, the neoclassical theory of growth suggests that economic growth depends on the level of saving and investment in human capital. Higher savings rates translate to higher economic growth, but it seems to ignore the impacts of decreasing aggregate demand in the economy which will accompany the savings. Second, it emphasizes the importance of investment in human capital as well as research and development to promote improvements in technology (Solow 1956:68-90 and Swan 340-355). Last, neoclassical economists favours the free markets and do not believe in fine-tuning the economy. They often stress the importance of privatization and elimination of government intervention as the source of economic growth. Milton Friedman, a modern champion of free markets sum this by saying this: "What we urgently need, for both economic stability and growth, is a reduction of government intervention, not an increase" (Friedman 1982, 38). They consider that the economy is built upon the interaction of firms and consumers in markets determined by price signals. However, economists such (North, 1981 and Stiglitz, 1996) emphasizes that the existence of a government is essential for economic growth. For instance, Joseph Stiglitz suggests that the developing economies the

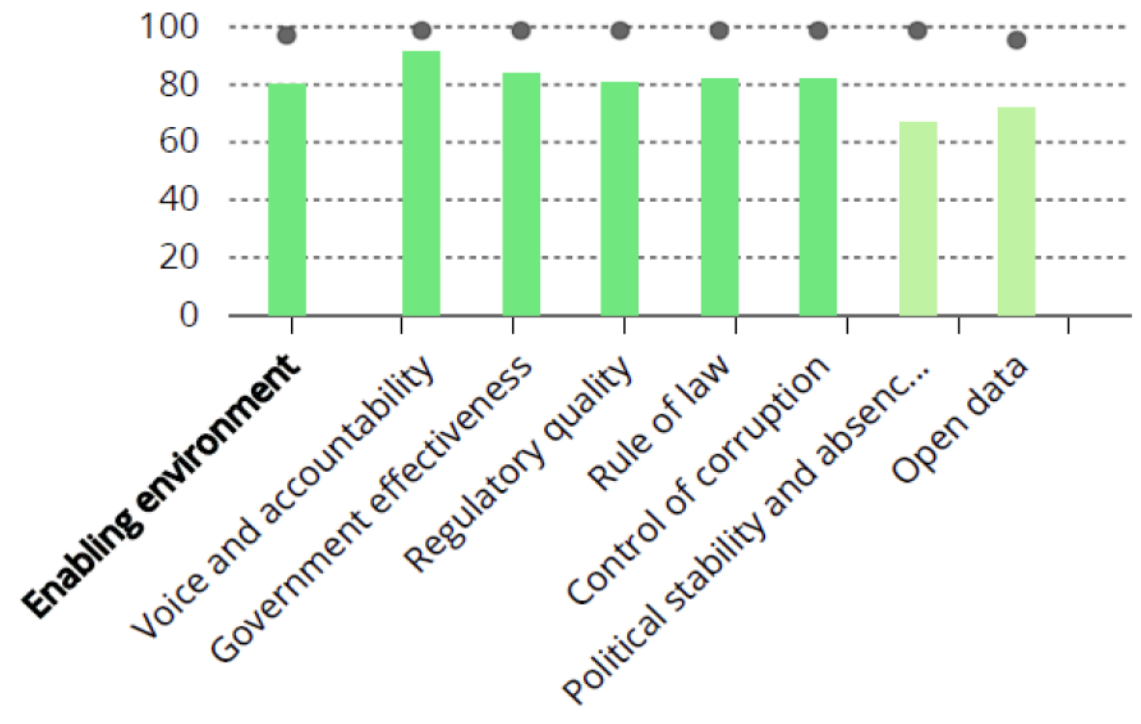

Figure 1: South Africa's Enabling Environment Score.

Source: Resource Governance Index, (2017). 
government must actively intervene because there is a widespread absence of markets and prices cannot perform their coordinating role (Stiglitz 1996, 160).

\section{GOOD GOVERNANCE AND SOUTH AFRICA}

South Africa has been a constitutional democracy since 1994 with a clear division of power between the executive, the legislature and the judiciary and there is a decentralisation of power between the national, provincial and local Government. Furthermore, the constitution clearly distinguishes the jurisdiction and the relationship between these three spheres of government. The importance of governance is mainly to promote the development and alleviating poverty, however measuring the quality of governance is not an easy task, but challenging. The neoclassical theory prescribes that maintaining law and order, especially affording property rights as the most acceptable rationale for government intervention.

As aforementioned, there are about six indicators of good governance, namely voice and accountability, which includes, citizen participation and independent media; political instability and violence; government effectiveness; regulatory quality; Rule of law; and Corruption. In recent years, it is generally argued that the effect of corruption in South Africa is seriously constraining the growth of the economy, and such can be attributed to bad governance in the country. Figure 1 above illustrates good' governance in South Africa' as measured by enabling business environment. The country scored well in enabling business environment (80 of 100 points), characterized by high government effectiveness, voice, and accountability, and with less performance political stability and access to open, data (Resource Governance Index, 2017).

The Wide Governance Indicators (WGI) are a set of composite indicators covering six dimensions of governance for over 200 countries over the two decades from 1996 to 2009. These dimensions of governance are: Voice and Accountability, Political Stability and Absence of Violence, Government Effectiveness, Regulatory Quality, and Rule of Law. These indicators inform and help us to quantify the good governance as a vital ingredient for economic growth. Most policy makers and academics accept the use of the WGI as the measure of good governance. However, Researchers such as (Arndt and Oman, 2008; Thomas, 2010) have criticized this measure of governance emphasizing that many of the indicators are not published, nor reproducible. In addition, they argue that it offers minor guidance for concrete arrangements to improve the quality of governance. Nevertheless, Figure 2 shows the South

Africa's effectiveness on the quality of governance as measured by WGI from 1996 to 2009. Figure 2 portrays that South Africa was too effective on issues that concern good governance scoring about 75 of 100 points. The WGI further reveals that in 2009 the country was less effective, recording a score of at least less 60 points. Interestingly, the country recorded a

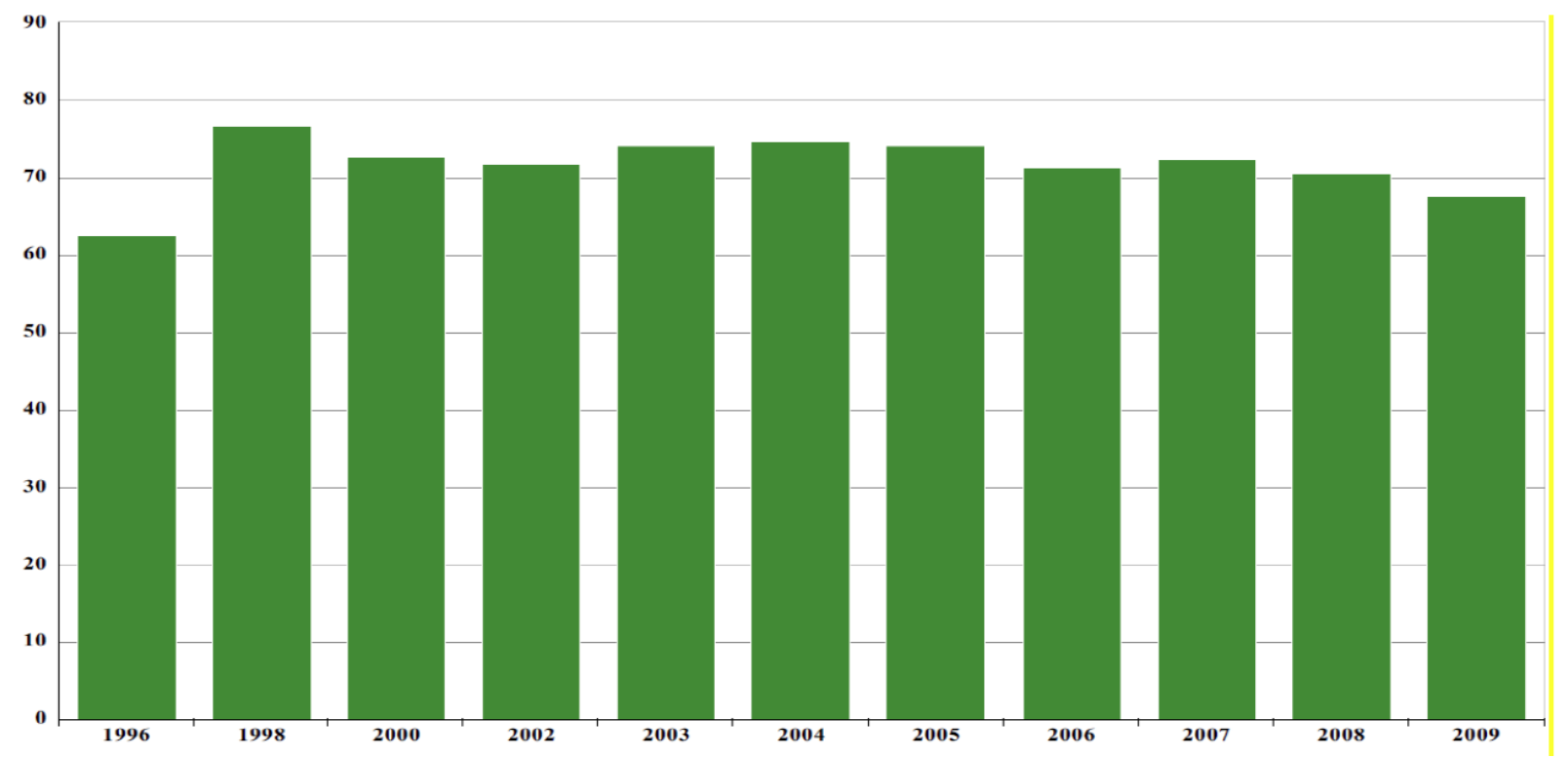

Figure 2: Worldwide Governance Indicators (WGI): South Africa's Government Effectiveness Rank. 


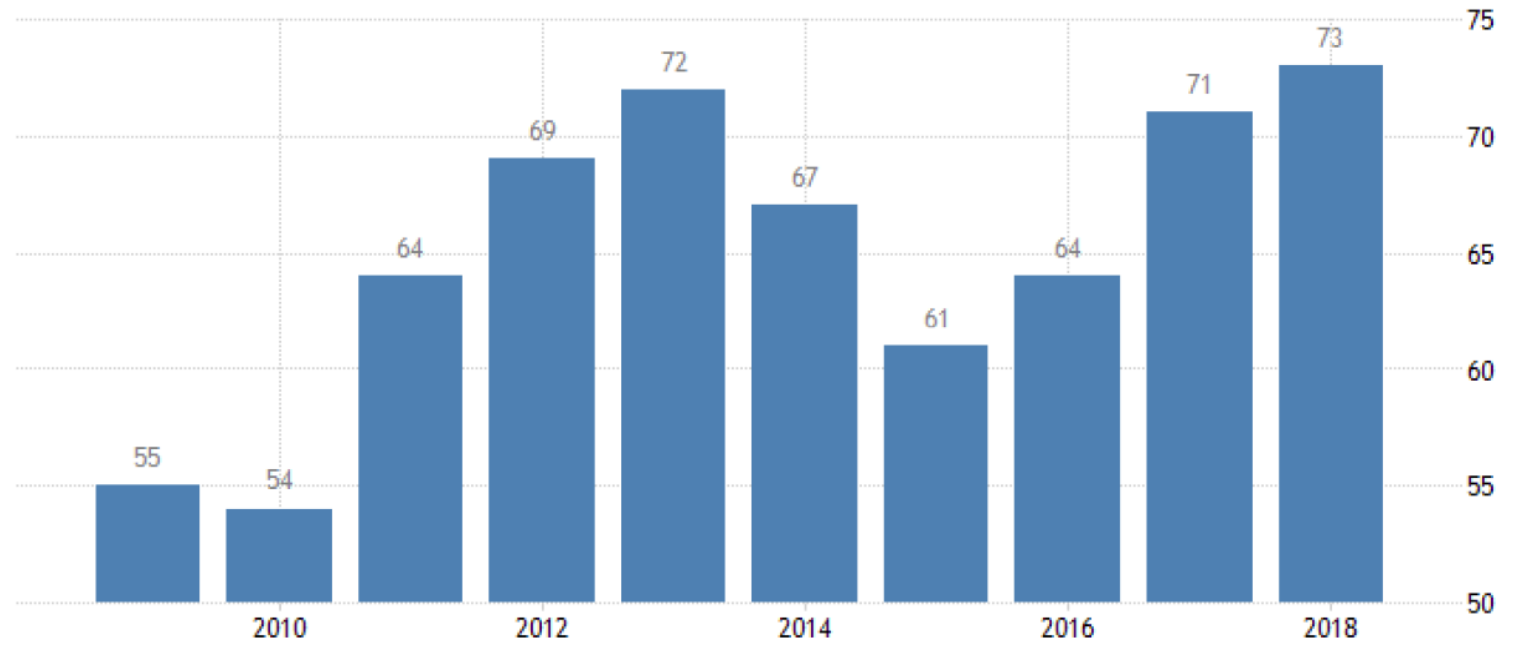

Figure 3: South Africa's Corruption Perceptions Index.

Source: Transparency International (2019).

negative annually GDP growth rate (-1.5 percent) in same year, but whether the poor performance of the economy was due to less governance issues is debatable.

South Africa has proper instruments to fight and reduce the unbridled level of corruption such as anti-corruption measures and agencies, however, she is struggling to arrest this problem. Corruption Perceptions Index (CPI) produced by Transparency International Index, South Africa's ranking was 73 out of 180 countries in 2018. The Index uses a scale of 0 to 100 , where 0 is highly corrupt and 100 is very clean. Furthermore, the index confirms that South Africa has rampant corruption, with the corruption perception score of 43 over 100 in 2018 . The issue that raises a concern is that South Africa is sitting in the 9th position in Sub-Saharan Africa, a worst-performing region in the world (Transparency International, 2019). Arguably, preventing corruption can assist in raising South Africa's revenues and ultimately the economy of the country.

\section{CONCLUSION AND RECOMMENDATIONS}

The most volatile current debate among South Africans from all walks of life, is how do the country grow the economy? And this is of no surprise because the country is currently battling to grow the economy, the unemployment rate is too high, and poverty and income inequality are worsening. Although the country is embellished by anti-corruption mechanisms, corruption remains rife. It is generally accepted that the nation's well-being depends on its economic health. Moreover, many people believe and claim that good governance is the elixir of poor economic growth. True, good, ethical governance really matters. But is good governance a main engineer for economic growth? Well, from the discussion above, it is learned that governments make policy changes in response to economic conditions. Indeed, most of these policies often used to engineer economic growth and to avoid bad economic challenges.

Unsurprisingly, advocates of good governance believe that in order to restore sustained growth in South Africa, the country must devotes more efforts in implementing governance reforms. In other words, to them, everyone would be better off if governance is perhaps managed judicious, transparent, accountable, participatory, responsive, well-managed, and efficient. As argued before, the challenge is that there is little evidence that good governance leads to rapid and inclusive economic growth. Moreover, it is important to recognise that the relationship between good governance and economic growth cut both ways. Meaning that poor economic growth might negatively affect the quality of governance. Strangely, scholars, policymaker and ordinary people often give much attention to the negative impacts that poor governance has on the economy.

Drawing from the neoclassical perspective, human capital development is the main source of economic growth. Certainly, Investment in education remarkable tool for poverty eradication. To be sure, education improves the productiveness of workers, consequently raising the total output (GDP) of the country. Therefore, South Africa should focus more on the reform of the educational system in order to ignite economic growth. 
Thus, improvements in the quality of labour, improve production capacity. Along this vein, Rawski (2011) maintains that China's economic ascent is due to human capital accumulation. The neoclassical economists also advocates for free markets. However, they make no doubt about the role of governance in facilitating a good business environment. On this basis, they do acknowledge the importance of good governance through affording citizens the property rights.

To sum, this article submits that for South Africa's economy to grow sustainably, the government should maintain a balance between human capital and good governance. Currently, the thorny concern is that the government is overestimating the impact of governance reform on economic growth. Consequently, underestimating human capital investment and its crucial role in growing the economy. Without a doubt, the quality of governance can determine the health of the economy. Thus, good governance minimizes the detrimental economic impacts from factors such inefficient, cronyism, and corruption. The closing remark is that focusing on good governance alone will undermine the efforts to restore the much needed sustainable growth.

\section{REFERENCES}

Acemoglu, Daron, Johnson, Simon, and Robinson, James A., 2005. "Institutions as a Fundamental Cause of Long-Run Growth." Pp. 385-472 in Handbook of Economic Growth. Vol. 1, edited by P. Aghion and S. Durlau. North Holland: Elsevier. https://doi.org/10.1016/S1574-0684(05)01006-3

African Development Bank Group (AFDB). (n). Worldwide Governance Indicators (WGI): South Africa's Government Effectiveness Rank. Retrieved June 16, 2019 (http://comstat.comesa.int/wiqcbkg/afdb-socio-economicdatabase-1960-2019?tsld=1518500).

Alchian, Armen A and Demsetz, Harold. 1972. "Production, information costs and economic organization." American Economic Review 62: 777-79.

Arndt, Christiane, and Oman, Charles. 2008. "The Politics of Governance Ratings". MGSoG: WP00. Maastricht, Netherlands.

Arrow, Kenneth J. 1962. "The economic implications of learning by doing." The Review of Economic Studies 29(3):155-173. https://doi.org/10.2307/2295952

Cass, David. 1965. "Optimum Growth in an Aggregative Model of Capital Accumulation." Review of Economic Studies, 32(3): 233-240. https://doi.org/10.2307/2295827

Clague, Christopher. 1997. "The new Institutional and Economic Development." Pp. 379 in Institutions and Economic Development: Growth and Governance in Less-Developed and Post-Socialist Countries, edited by C. Clague. London: The John Hopkins University Press.

Coase, Ronald H. 1974. "The choice of the institutional framework: a comment." Journal of Law and Economics 17 (2): 493-496. https://doi.org/10.1086/466803
Friedman, Milton. 1982. Capitalism and Freedom. Chicago and London: University of Chicago Press, Bank. Retrieved June 16,2019 https://doi.org/10.1111/gove.12035

Fukuyama, Francis. 2013. "What is governance? Governance." 26(3): 347-368. Retrieved June 16, 2019. https://doi.org/10.1111/gove.12035

Johnston, Michael. 2004. "Good governance: Rule of law, Transparency and accountability," Colgate University New York. Retrieved September 10, 2019 (http://unpan1.un.org/ intradoc/groups/public/documents/un/unpan010193. pdf).

Kaldor, Nicholas. 1956. "Alternative theories of distribution." The Review of Economic Studies 23(2):83-100. https://doi.org/10.2307/2296292

Kaufman, Bruce E. 2000. "Union governance and democracy: introduction." Journal of Labor Research. 21(4):1-2. https://doi.org/10.1007/s12122-000-1000-9

Kaufmann, Daniel and Kraay, Aart. 2002. "Growth without governance," Policy Research Working Paper Series 2928, World Bank.

Kaufmann, Daniel. 2005. "Myths and realities of governance and corruption". In Global Competitiveness Report 2005-06. Retrieved June 16, 2019 (http://mpra.ub.unimuenchen.de/ 8089).

Kaufmann, Daniel, Kraay, Aart, and Mastruzzi, Massimo. 2010. "The Worldwide Governance Indicators Methodology and Analytical Issues." Working Paper no. 5430. World Bank Policy Research Department, Washington, DC. Retrieved January 20, 2019 (http://info.worldbank.org/governance/ wgi/index.asp).

Knack, Stephen and Keefer, Philip. 1995. "Institutions and economic performance: cross-country tests using alternative institutional measures." Economics and Politics 7(3): 207227.

https://doi.org/10.1111/j.1468-0343.1995.tb00111.x

Knack, Stephen. 2003. "Democracy, Governance and Growth." Ann Arbor: The University of Michigan Press. https://doi.org/10.3998/mpub.23499

Koopmans, Tjalling C. 1965. "On the concept of optimal economic growth." Pontificia Academia Scientiarum Scripta Varia 28(1):225-87.

Kurtz, Marcus and Schrank, Andrew. 2007. "Growth and Governance: Models, Measures, and Mechanisms." Journal of Politics 69(2):538-554. https://doi.org/10.1111/j.1468-2508.2007.00549.x

Langbein, Laura and Knack, Stephen. 2010. "The Worldwide Governance Indicators: Six, One, or None?" Journal of Development Studies 46(2):350-370. https://doi.org/10.1080/00220380902952399

Mankiw, Nicholas G. 1992. "Commentary: the search for growth," Proceedings - Economic Policy Symposium - Jackson Hole, Federal Reserve Bank of Kansas City, Pp. 87-92.

Mauro, Paolo. 1995. "Corruption and Growth." Quarterly Journal of Economics 110(3): 681-712. https://doi.org/10.2307/2946696

Meade, James E. 1955. The Theory of Customs Unions. NorthHolland Publisher: Amsterdam

Mijiyawa, Abdoul G. 2013. Determinants of property rights institutions: survey of literature and new evidence. Economics of Governance 14(2): 127-183. https://doi.org/10.1007/s10101-013-0126-1

Morlino, Leonardo. 2004. "What is 'good' democracy?" Democratisation 11(5): 10-32. https://doi.org/10.1080/13510340412331304589

North, Douglass C. 1990. "Institutions, Institutional Change, and Economic Performance". NewYork: Cambridge University Press. https://doi.org/10.1017/CBO9780511808678 
Olson, Mancur. 1996. "Big Bills Left on the Sidewalk: Why Some Nations are Rich and, and Others Poor." Journal of Economics Perspectives 10(2): 3-24. https://doi.org/10.1257/jep.10.2.3

Ramsey, Frank P. 1928. "A Mathematical Theory of Saving." Economic Journal 38(152):543-59. https://doi.org/10.2307/2224098

Rawski, Thomas G. 2011. "Human resources and China's long economic boom." China Economic Quarterly 10(4): 11531186. https://doi.org/10.1353/asp.2011.0028

Resource Governance Index. 2017. South Africa's Enabling Environment Score. Retrieved March 20, 2019 (https://resourcegovernanceindex.org/).

Romer, Paul M. 1986. "Increasing Returns and Long-Run Growth," Journal of Political Economy, 94(5):1002-37. https://doi.org/10.1086/261420

Rothstein, Bo A. M. 2011. The Quality of Government: Corruption, Social Trust and Inequality in a Comparative Perspective. Chicago: University of Chicago Press (in press).

Schneider, Hartmut. 1999. Participatory Governance: The Missing Link for Poverty Reduction, Policy Brief No. 17, Paris: OECD Development Centre. Retrieved March 20, 2019. https://doi.org/10.1787/888041015581

Smith, Adam. 1776. The Inquiry into the Nature and Causes of the Wealth of Nations, reprint (1994), Modern Library Edition. https://doi.org/10.1093/oseo/instance.00043218

Solow, Robert. 1956. "A contribution to the theory of economic growth." Quarterly Journal of Economics 70(1): 65-94. https://doi.org/10.2307/1884513

Stiglitz, Joseph E. 1987. "The cause and consequences of the dependence of quality on price." Journal of Economic Literature, 25(1):1-48.
Stiglitz, Joseph E. 1996, "Some lessons from the East Asian miracle", The World Bank Research Observer, 11(2): 151-77. https://doi.org/10.1093/wbro/11.2.151

Swan, Trevor W. 1956. "Economic Growth and Capital Accumulation." Economic Record, 32: 334-361. https://doi.org/10.1111/j.1475-4932.1956.tb00434.x

Thomas, Melissa A. 2010. "What Do the Worldwide Governance Indicators Measure?" The European Journal of Development Research. 22(1): 31-54. https://doi.org/10.1057/ejdr.2009.32

Transparency International, 2019. South Africa's Corruption Perceptions Index. Retrieved February 10, 2019 (https://www.transparency.org/country/ZAF).

UNDP, 2002, Giving Voice to the Voiceless: Good Governance USAID, 2002, "USAID Supports Good Governance," Retrieved February 10, 2019 (http://www.docstoc.com/ docs/673298/USAID-Supports-Good).

World Bank. 2018. Overcoming Poverty and Inequality in South Africa: An Assessment of Drivers, Constraints and Opportunities. The World Bank: Washington DC. Retrieved February10,2019(http://documents.worldbank.org/curated/en /530481521735906534/pdf/124521-REV-OUO-South-AfricaPoverty-and-Inequality-Assessment-Report-2018-FINALWEB.pdf).

World Bank. 2017. Doing Business 2017: Equal Opportunity for All. Washington, D. C: World Bank. Retrieved February 10, 2019. https://doi.org/10.1596/978-1-4648-0948

World Bank 2001. Tanzania at the Turn of the Century: From Reform to Sustained Growth and Poverty Reduction. World Bank Country Study. The World Bank: Washington DC. RetrievedFebruary10,2019(http://documents.worldbank.org/c urated/en/364061468778487238/pdf/multiopage).

\section{DOI: https://doi.org/10.6000/1929-7092.2019.08.132}

(C) 2019 P. Madumi; Licensee Lifescience Global.

This is an open access article licensed under the terms of the Creative Commons Attribution Non-Commercial License (http://creativecommons.org/licenses/by-nc/3.0/) which permits unrestricted, non-commercial use, distribution and reproduction in any medium, provided the work is properly cited. 